\title{
Developing your career as a haematologist
}

\author{
Jacqui Wise \\ London, UK
}

Haematology is a flexible specialty that offers the opportunity to develop special interests in a variety of clinical and laboratory areas. It is also possible to combine a clinical and academic career.

\section{Consultant posts}

A certificate of completion of training is awarded by the General Medical Council once a trainee successfully completes specialist training, has passed the Fellow of the Royal College of Pathologists examination, and is deemed competent by the specialist advisory committee. They will then be placed on the specialist register and allowed to apply for consultant posts.

The Royal College of Pathologists 2017 census showed there were 1035 consultant haematologists across the UK. The 2018 workforce survey identified 76 consultants working in paediatric haematology with a further eight vacant consultant posts in that area

Haematologists are responsible for the management of acute and chronic haematological conditions in NHS hospitals; in addition, they provide clinical oversight for haematology laboratory services and a liaison service which supports all other areas of the hospital and community medical services. Haematology consultant posts range from general hospital posts which cover all areas of haematology to more specialist posts in larger centres

Haematology offers the opportunity to further specialise in a number of areas including advanced diagnostics, bone marrow transplant, haemato-oncology, haemostasis and thrombosis, paediatric haematology, red cell and haemoglobinopathy disorders, and transfusion medicine. Before applying for a consultant post, many haematologists will take on a fellowship post either in the UK or abroad in order to broaden their experience and increase their employability. Fellowship posts and consultant posts are advertised on the BMJ Careers website (jobs.bmj.com) and the NHS Jobs website (www.jobs.nhs.uk).

\section{Sub-specialties}

Sub-specialties within haematology include: haemato-oncology or haematological malignancy; haemostasis and thrombosis; paediatric haematology; red cell and haemoglobinopathy disorders; and transfusion medicine.

\section{Haemato-oncology or haematological malignancy}

This covers conditions such as acute and chronic leukaemias, lymphoma, and multiple myeloma. Haematologists will diagnose and type cancers to help develop the best treatment plan for the patient. There is the opportunity to use new therapies developed as a consequence of the latest scientific breakthroughs including chemotherapy, radiotherapy, and genetically engineered antibodies and lymphocytes.

\section{Haemostasis and thrombosis}

This includes diagnosing and monitoring patients with congenital and acquired disorders of haemostasis and blood coagulation and management of antithrombotic therapies. Some hospitals have centres that focus on specific disorders such as haemophilia.

\section{Paediatric haematology}

This is an exciting and rewarding sub-specialty of haematology. Most specialist paediatric haematologists will have trained specifically in paediatric haematology. However, all haematologists, especially those working in district general hospitals and those with onsite neonatal units will be required to advise on, and sometimes directly manage, haematological problems in children. Therefore, all haematology trainees spend at least six months of training learning about childhood blood disorders.

Adult haematology trainees who develop an interest in paediatric haematology during their paediatric attachment may have their option to complete training in paediatric haematology but may have to undertake a period of core paediatric training.

\section{Red cell and haemoglobinopathy disorders}

This includes the management of anaemias, sickle cell disease, and thalassemia. Haematologists would be involved in the initiation of transfusion programmes, immunosuppressant drugs, and sometimes stem cell transplantation.

\section{Transfusion medicine}

Most large centres will have a dedicated transfusion medicine haematologist. They would be responsible for performing routine blood grouping, antibody identification, red cell phenotyping, crossmatching, and other pre-transfusion tests. Haematologists are also involved in developing and implementing transfusion policy within a trust including blood conservation and transfusion safety. NHS Blood and Transplant also employs haematologists who are involved at a national level promoting appropriate blood use and being involved in blood product development. ${ }^{1}$ 


\section{Academic opportunities}

Haematology trainees may have the opportunity to do research leading to a doctorate either before or after their specialist training. Many cutting edge discoveries regarding the molecular mechanisms of disease and their subsequent applications in clinical practice have first occurred in haematological conditions. The British Society for Haematology offers scholarships and grants to attend international conferences, undertake research and advance haematology education. ${ }^{2}$

Those with a particular interest in research may have trained on an academic pathway. Entry into an academic career would usually start with an academic clinical fellowship (ACF) in the first or second year of specialty training and may progress to a clinical lectureship in the third or subsequent years. Some trainees that begin with an ACF post then continue as an specialty trainee on the clinical programme after the fourth year. Applications for ACF posts are coordinated by the National Institute for Health. Further information can be found on the Research Trainees Coordinating Centre website. ${ }^{3}$

\section{Continuing professional development}

Consultants are expected to continue developing their professional skills throughout their working lives. They can develop their skills through continued professional development activity in one or more areas of special interest. More details are on the Royal College of Pathologists' website. ${ }^{4}$

\section{Managerial opportunities}

There are managerial opportunities for consultant haematologists. These include being lead NHS consultant for the team (clinical lead), lead NHS consultant for the department (clinical director), or lead NHS consultant for the trust (medical director).

\section{Education and training opportunities}

Most NHS consultants will be involved in some way with the clinical and educational supervision of junior doctors. There are also other opportunities.

These include becoming the consultant responsible for the postgraduate medical training in a hospital (the director of postgraduate medical education) or the consultant overseeing the education of the cohort of trainee doctors within a local Health Education England office (the deanery training programme director).

\section{Working abroad}

There are opportunities for haematologists to work or volunteer abroad-particularly in the field of sickle cell anaemia. Further information can be found on the BMA website. ${ }^{5}$ Opportunities can also be found with Médecins Sans Frontières, ${ }^{6}$ MERLIN, ${ }^{7}$ and Voluntary Service Overseas. ${ }^{8}$

NHS Blood and Transplant. www.nhsbt.nhs.uk.

British Society for Haematology. Grants. https://b-s-h.org.uk/grants.

3 National Institute for Health Research. How we are managed. www.nihr.ac.uk/about-us/ how-we-are-managed/managing-centres/about-the-trainees-coordinating-centre.htm.

Royal College of Pathologists. Continuing professional development. www.rcpath.org/ profession/continuing-professional-development-cpd.html

5 BMA. Volunteering as a SAS doctor or consultant. www.bma.org.uk/advice/career/goingabroad/volunteering-abroad/sas-and-consultant.

6 Médecins Sans Frontières. www.msf.org.uk.

7 Medical Emergency Relief International. www.merlin.org.uk.

8 VSO International. www.vsointernational.org

Published by the BMJ Publishing Group Limited. For permission to use (where not already granted under a licence) please go to http://group.bmj.com/group/rights-licensing/ permissions 